\title{
How Can Korea be a Role Model for Catch-up Development?
}

\author{
A 'Capability-based View'
}

Keun Lee*

June 2009

\begin{abstract}
There is some scepticism about Korea as role model of development as the Korean model involved a considerable degree of state activism, unacceptable in today's global environment. This paper propose a 'capability-based view' of the country's catch-up development, arguing that the real lesson from Korea is not the role of government but the fact that it was able to strengthen the capability of firms, thus inducing sustained growth for several decades. This paper points to the mid 1980s as the critical juncture in this process of capability-building, as the Korea emphasized in-house R\&D in private sectors, pushing the aggregate R\&D/GDP ratio to the threshold level of 1 per cent or more. This led to another core aspect of the Korean model-continuous upgrading within the same industries as well as advancing successive entries into new promising industries. The paper argues that without capability-building, devaluation or standard trade liberalization alone cannot bring sustained catch-up as these often result in short-run, albeit temporary, export booms. The study analyses how Korea utilized various access modes to learning and knowledge to enhance its technological capabilities, and concludes with a discussion of the transferability of the Korean lessons to other countries.
\end{abstract}

Keywords: Korea, development, catch-up, role model, capabilities

JEL classification: O10, O20, O53

Copyright (C) UNU-WIDER 2009

* School of Economics, Seoul National University, Seoul, email: Kenneth@snu.ac.kr; klee1012@plaza.snu.ac.kr

This study has been prepared within the UNU-WIDER project on Country Role Models for Development Success, directed by Augustin Kwasi Fosu.

UNU-WIDER gratefully acknowledges the financial contributions to the project by the Finnish Ministry for Foreign Affairs, and the financial contributions to the research programme by the governments of Denmark (Royal Ministry of Foreign Affairs), Finland (Finnish Ministry for Foreign Affairs), Sweden (Swedish International Development Cooperation Agency-Sida) and the United Kingdom (Department for International Development). 


\section{Acknowledgements}

An earlier version of this paper was presented at the UNU-WIDER conference on Country Role Models for Development Success, 13-14 June 2008, in Helsinki. The author would like to thank Augustin K. Fosu, the project director, for his guidance and suggestions.

\section{Acronyms}

IPO initial public offering

IPRs intellectual property rights

JVs joint-ventures

M\&As mergers and acquisitions

MNCs multinational corporations

NIEs newly industrialized economies

OBM original/own brand manufacturing

ODM original design manufacturing

OEM original equipment manufacture

SMEs small and medium enterprises

The World Institute for Development Economics Research (WIDER) was established by the United Nations University (UNU) as its first research and training centre and started work in Helsinki, Finland in 1985. The Institute undertakes applied research and policy analysis on structural changes affecting the developing and transitional economies, provides a forum for the advocacy of policies leading to robust, equitable and environmentally sustainable growth, and promotes capacity strengthening and training in the field of economic and social policy making. Work is carried out by staff researchers and visiting scholars in Helsinki and through networks of collaborating scholars and institutions around the world.

www.wider.unu.edu

publications@wider.unu.edu

UNU World Institute for Development Economics Research (UNU-WIDER)

Katajanokanlaituri 6 B, 00160 Helsinki, Finland

Typescript prepared by Liisa Roponen at UNU-WIDER

The views expressed in this publication are those of the author(s). Publication does not imply endorsement by the Institute or the United Nations University, nor by the programme/project sponsors, of any of the views expressed. 


\section{Introduction}

Korea has been one of the most successful latecomer economies to achieve rapid economic growth and is approaching the ranks of the advanced economies, with per capita GDP of US\$20,000 in 2007 compared to approximately US\$160 in 1960 (Lee and Kim 2009). While Korea has often been proposed as a role model for other developing countries, there is also some scepticism. Such scepticism seems to stem from the perception that the Korean model involved a great degree of state activism, including targeted protection for some industries or firms-an intervention not acceptable in today's global environment. The perception continues to prevail, as early literature tended to focus on the role of the government versus markets in catching-up development (Amsden 1989; Chang 1994; World Bank 1993). But another stream of literature, namely a technology-based view (such as OECD 1992; Hobday 1995; L. Kim 1997a; Dahlman, Westphal and Kim 1985), contends that Korea and other newly industrialized economies (NIEs) have tried to catch up by assimilating and adapting the more or less obsolete technology of the advanced countries (Vernon 1966; Utterback and Abernathy 1975; Kim 1980).

This paper intends to propose a 'capability-based view' of the Korean and Asian experience in the catching-up development process. This approach can be considered an extension of the technology-based view, albeit somewhat removed from the government-market dichotomy as its microeconomic foundation is more sound. We are taking this view because the real lesson from Korea is not the role of government in economic development but the fact that the country was able to strengthen the capability of firms, thus inducing sustained growth for several decades.

Sustaining long-term growth is not easy. There are numerous cases of macro-oriented reform bringing immediate recovery but without it being sustained, and eventually the economy is faced with another crisis (Lee 2006). The most fundamental barrier to sustained development is local capabilities. Without a certain critical degree of capabilities, growth, which is based on lower wage rates or simple price competitiveness, tends to be short-lived. The Korean success was based on capabilities, and since the mid 1980s Korea has emphasized in-house R\&D in private sectors, pushing the aggregate $\mathrm{R} \& \mathrm{D} / \mathrm{GDP}$ ratio to the threshold level of 1 per cent, and eventually to 2.5 per cent or higher.

One of the most obvious differences between the developed and developing countries is their per capita GDP. But what accounts for the differences in income levels? These result from the varying capabilities of each country, including the capability to produce and sell internationally competitive products for long periods. One core element of the Korean model was its focus on building these capabilities, which enabled the economy to achieve continuous upgrading within the same industries as well as advancing successive entries (another kind of upgrading) into new promising industries.

But it is not easy to enhance capabilities. Mainstream economics tends to concentrate on macroeconomic stabilization and trade liberalization, but these are only remotely connected to capacity-building, if at all. This bias in economics dates back to the intrinsic limitations of mainstream economics when the word 'capabilities' (and by implication, 'learning') did not exist. Mainstream economics advocates the optimization of resources, but starts from the implicit assumption that all resources (inputs or capabilities) are already in existence and the only task is to find their most efficient 
utilization. But in reality, most of the developing countries do not have to worry about the optimal usages of resources (capabilities) simply because they are not available. For these countries, the more critical issue is how to strengthen such capabilities.

Next, we define capability-building and successive upgrading, the essence of the Korean model, and then discuss how the country has overcome the disadvantage of being a latecomer to capability-building. Section 3 elaborates the process of capabilitybuilding over four stages. Section 4 summarizes each capability-building phase, highlighting the first half of the 1980s as the critical juncture in the process. The final section discusses the transferability of the Korean model to other countries.

\section{Capability-building and successive upgrading as the essence of the Korean model}

\subsection{Development as a process of capability-building}

Openness and export promotion have generally been regarded as key policy ingredients for the developing countries. Thus, many countries simply resorted to devaluation or standard trade liberalization, which led to export booms from the price effects and certain stabilization of external balances. However, there are numerous cases of macrooriented reform bringing immediate, albeit unsustained, recovery and eventually another round of crisis. For example, the three reform cycles in Indonesia (1983-91, 1994-97 and the post-1998) show that rapid success with macro-reform, if not supported by microeconomic changes, tends to fade fairly soon, triggering another balance-ofpayment crisis. A similar pattern is unfolding in Nepal with respect to the 1990s reforms (K. Lee 2006).

Korea was in the same predicament as the other developing countries, faced with continual external imbalances and persistent trade deficits during the first two decades of industrialization in the 1960s and 1970s. However, since the 1970s the government has put emphasis on technological development by publicly funding and conducting $R \& D$. The results were shared with private firms, private $R \& D$ was promoted with tax incentives and in the 1980s a public-private joint R\&D was set up for bigger, risky projects. Intensification of $R \& D$ expenditure and a focus on higher education laid the basis for knowledge-driven growth. This is apparent in the rise in US patents filed by Koreans. In the early 1980s, approximately fifty US patent applications were instigated by Koreans, similar to the situation of the Latin American countries. The R\&D/GDP ratios for east Asian and Latin American countries were also similar, around 0.5 per cent (Table 1). But by 2000, Korea was filing more than 5,000 US patents per year and its $\mathrm{R} \& \mathrm{D} / \mathrm{GDP}$ ratio was 2.5 per cent. In contrast, the ratio for most of the Latin American countries had remained around 0.5 to 1.0 per cent, and none of Latin American countries were filing more than 1,000 applications annually.

This often unnoticed policy initiative was successful in strengthening the manufacturing sector, an important factor behind the late 1980s trade surplus, the first in the modern history of Korea. Since then, Korea has been able to overcome the persistent trap of external imbalances or stop-go cycles of crisis and reforms. Countries that followed the Washington consensus, focusing on macroeconomic stabilization and trade liberalization, experienced some improvement but this tended to be short-lived. When 
Table 1

R\&D/GDP ratios in selected countries

\begin{tabular}{lcclcc}
\hline & \multicolumn{2}{c}{1965} & 1980 & 2000 \\
\hline Korea & 0.5 & & 0.56 & 2.65 \\
Taiwan & & & 0.71 & 2.05 \\
Philippines & 0.2 & & 0.2 & \\
Thailand & 0.3 & $(1969)$ & 0.3 & $(1985)$ & 0.25 \\
Malaysia & & & 0.10 & $(1988)$ & 0.49 \\
China & & & 0.68 & $(1985)$ & 1.00 \\
India & 0.4 & $(1968)$ & 0.7 & $(1982)$ & 0.85 \\
Brazil & 0.3 & $(1974)$ & 0.6 & $(1982)$ & 1.04 \\
Argentina & 0.2 & $(1969)$ & 0.5 & & 0.44 \\
Chile & & & 0.4 & & 0.53 \\
Mexico & 0.1 & $(1970)$ & 0.6 & $(1984)$ & 0.37 \\
Ghana & 0.2 & $(1966)$ & 0.9 & $(1976)$ & \\
Nigeria & 0.5 & $(1969)$ & 0.3 & $(1977)$ & 0.62 \\
South Africa & & & 0.89 & $(1985)$ & (avg. of 1988 \& 2002) \\
\hline
\end{tabular}

Source: Authors' database detailed in Lee and Kim (2009); K. Lee (2006).

the momentum of the initial macro-based reform slowed down and the economy started to show signs of a crisis or recession, bolder economic reforms were tried in the next round. These included financial liberalization or capital market liberalization, which exposed the economy to volatile short-term finance capital. When financial liberalization lacked proper design and management, it often led to a foreign borrowing spree, speculation, a financial bubble, and ultimately another financial crisis. Although Rodrik (1996b) acknowledges the importance of the sequential adoption of the ten policy recommendations of the Washington consensus, he overlooks the fact that east Asia since the mid 1980s had more advanced capabilities already prior to deeper marketization.

It needs to be noted that one of the most important elements of Korea's success was the emphasis on capability and technological development, which may lead to a consolidation of private exporting and R\&D capacity. Without strengthened R\&D capability, sustained export growth is not possible. The difference between the more and less successful Asian economies was the priority given to technology and, in particular, higher education to enhance long-term growth potential. These are missing from the Washington consensus, even though they can be considered as the distinctive core elements of the approach adopted in northeast Asia.

A recent World Bank assessment of the reform decade of the 1990s concedes that growth entails more than the efficient use of resources and that growth-oriented actions, for example, on technological catch-up or encouragement of risk-taking for faster accumulation may be needed (World Bank 2005: 11). Also, recent ECLAC studies on reform in Latin America find that macroeconomic stability is not a sufficient condition for ensuring long-term growth, which is linked more closely to the dynamics of the production structure. Furthermore, a well-functioning broader institutional context and infrastructure are essential, but these generally do not play a direct role in bringing about changes in the momentum of growth (Ocampo 2005). Then, our point is that microeconomic interventions should be combined with capacity-enhancing elements (technology and education), so that the costs of distortions (rent-seeking) can be offset by growth-generated new additional rents. 
When we regard catching-up growth as a capacity-building process, we are considering the capacity of private corporations. The ability of latecomer economies to promote vibrant private companies is the most important fundamental criterion that determines the success or failure of economic development or growth. If the risks for private capital are too high, these may initially be state-owned firms, but they should be steered towards private ownership (i.e., making them 'public' through an initial public offering (IPO) as soon as possible. This is rarely stated explicitly, which is why we are highlighting it as the main element of the Korean model.

Among the various aspects of capacities, technology needs to be singled out because without it, sustained growth is impossible. In this era of open competitive markets, private companies cannot sustain momentum with cheap products; they must move up to higher value-added goods through continual upgrading, improvement and technological innovation. Furthermore, whenever possible, private companies, including locally controlled joint-ventures (JVs), should be 'local' enterprises, not the foreigncontrolled subsidiaries of multinational corporations (MNCs). The multinationals are continually on the move around the world, seeking cheaper wages and bigger markets, and cannot be relied upon to generate sustained growth in specific localities or countries. MNCs are, however, useful channels for knowledge transfer and learning.

\subsection{Successive upgrading of capabilities and entries into new industries}

Some authors, such as Hobday (2000) and Teece (2000), emphasize the potential in original equipment manufacture (OEM) based outward-oriented growth, but we focus on the limitations imposed by these growth strategies as they are contingent on MNC decisions whether or not to relocate to the newly emerging cheap-wage countries.

A close examination of a successful catching-up economies, like Korea, indicates that advancement within the same industry or upgrading successive entries (constituting another type of upgrading) into new promising industries evolved over the course of industrial development. Our argument is that without the development of these two strands of upgrading, the chances for successful catch-up are smaller. There are two reasons for this; one impacting from the latecomer side and the other affecting from the front-runner side (Lee and Mathews 2008).

First, the impact from the latecomer perspective: successful OEM strategy tends to increase their wage rates accordingly, but it is also a fact that new cheaper labour sites continue to emerge in next-tier countries and these can overtake the latecomer position in the global value-chains. This forces an upward movement towards higher valueadded activities within the industries that can accept higher wage rates and towards sectors where the next-tier countries are unable to compete.

Second, in the case of front-runners, the innovators in these countries tend to generate new industries that correspond to higher value-added and the front-runners will turn to the latecomers for outsourcing. As innovations develop (new products and new industries), old industries mature, become obsolete and downgrade to lower value-added activities, forcing firms to seek to opportunities in the newly emerging and high valueadded industries. Firms are forced to travel this road of renewal or be overtaken by the followers. 
The necessity for these two types of upgrading extends partly from the international industrial lifecycles wherein new industries tend to be created in the developed world, and the latecomer countries and firms inherit these once they mature and their products become standardized. Given this lifecycle, an important feature of successful catchingup is the ability to enter at earlier (higher value-added) stages of the cycle, and this is possible only with enhanced absorption capability. Otherwise, the alternatives are lower-wage activities or industries, with limited opportunities for long-term success.

Such a dynamic view of industrial change is clearly contradictory to the mainstream emphasis on static comparative advantages; uncritical application of industrial change can lock the world at a stage whereby the developed countries specialize more in the high value-added or high-margin products while the developing countries are tied to low value-added or low-margin products. Furthermore, no guidance is offered on how to manage the transition from marginal-profit production to high value-added production, which makes the prospects of upgrading development uncertain.

There has been a dramatic change in the export structure of Korea, starting from the labour-intensive goods (apparel) to automobiles and electronic goods. The share of exports in total GDP was less than 2 per cent in the early 1960s or at the beginning of the industrial take-off, reaching 10 per cent in the early 1970s and 30 per cent by the mid 1980s. This growth in exports was first driven by such labour-intensive goods as apparel and footwear. Their share increased rapidly in the 1960s and 1970s to 10 per cent of total exports by 1965 and almost 30 per cent by the early 1970s. Since then, the share of apparel and footwear dropped to about 10 per cent in 1990 and to less than 3 per cent by 2000, as they were replaced by other higher-valued goods, such as electric and electronics goods and automobiles. The share of these latter items increased to about 10 per cent by the mid 1970s, accounting for 20 per cent two decades later, and finally almost 30 per cent by 2005.

Behind this change in export structure is the continuous improvement of firm-level capabilities, upgraded from OEM to ODM and then to OBM (Mathews and Cho 2000; Hobday 2000; Lee 2005). This became necessary because the forerunning vendor firms tended to transfer their OEM orders to lower-wage sites, and latecomers needed to expand to higher value-added orders. There are many instances of upgrading within the same industry in east Asia. For example, semiconductor firms in Korea and Taiwan started from IC-packaging or testing (low value-added activities), then moved to ICfabrication and eventually to IC-design (highest valued-added) (Mathews 2005, 2006).

In Korea, there are also many cases of successive entry into higher value-added industries. The Samsung group is well-known for its successive convergence of new industries during its 60-year history. As shown in Figure 2, Samsung started in light manufacturing industries (textiles) but then expanded into consumer electronics, followed by semiconductors and telecommunications and finally flat panel displays, etc. In this process, the state had an important role in providing institutional support through joint R\&D and technology transfer arrangements, as well as tax and credit concessions for newer industries. 
Figure 1.

Changing trend in the composition of major export items, 1960-2005

(\% share in total exports)

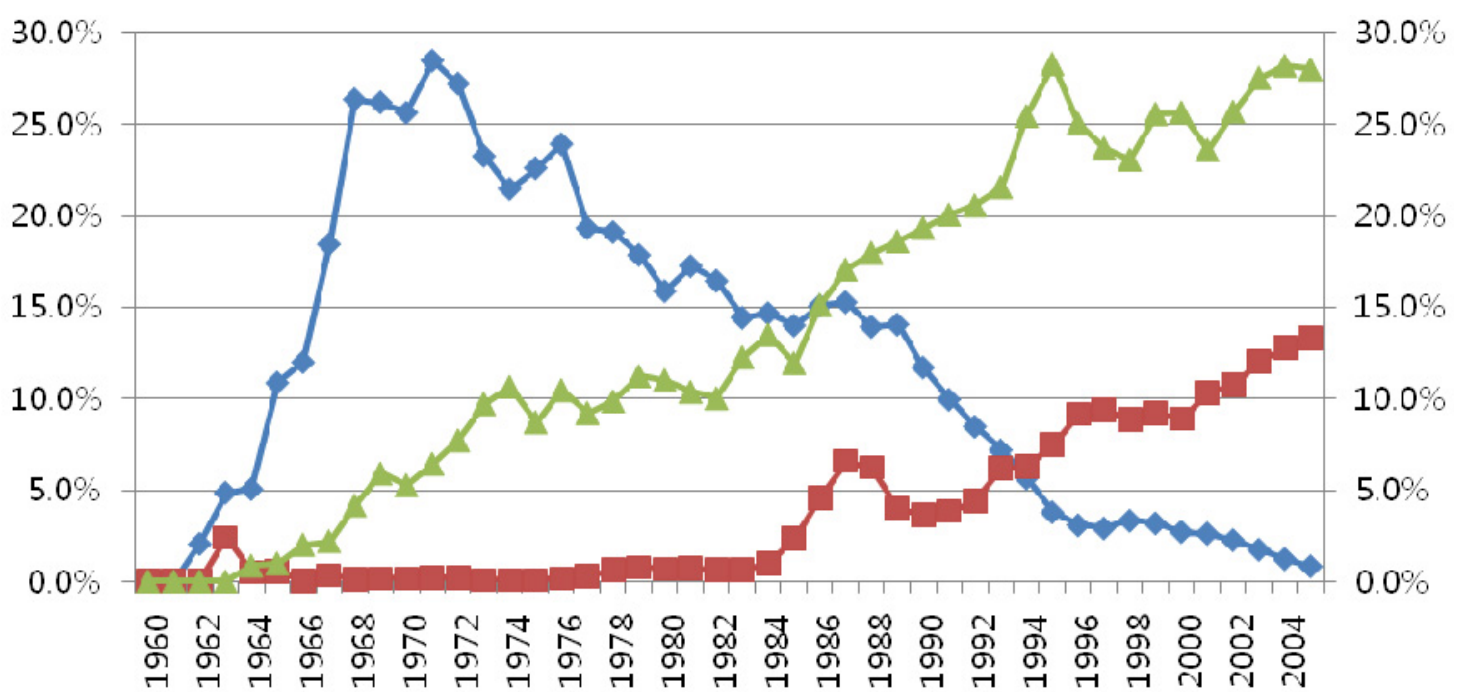

$\leadsto$ Apparel - Automobile - Electric

Equipment

Source: Drawn by the author using data from the Korea International Trade Association Database (available at www.kita.net), and the United Nations Commodity Trade Statistics Database (available at www.comtrade.un.org), based on MTI Code, formulated by ministry of knowledge and economy, or by the relevant SITC Rev. 1 Code.

Figure 2

Changes in the Samsung Groups' Sales Composition

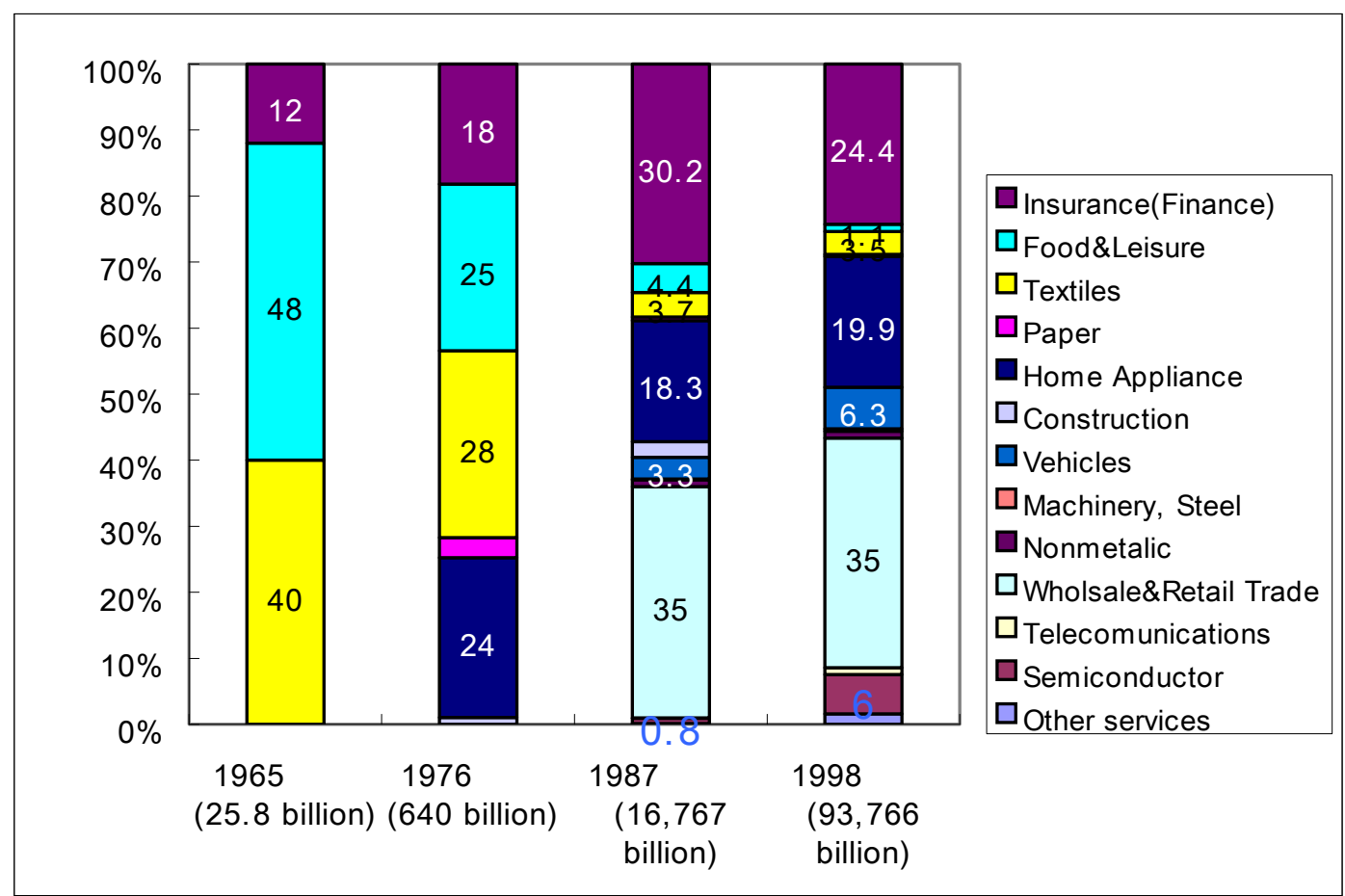

Note: $\quad$ Numbers are share percentages in total sales (billion won).

Source: Figures drawn by the author using the data in Chang (2003). 
The illustration of upgrading and market entry shows that these two processes are interlinked: successive entry is possible only after latecomer firms first acquire the design capability needed for upgrading in a given industry. In other words, to overcome problems related to the OEM-based growth, latecomer firms should first acquire the necessary design capability, and with these design capabilities, they tend to become late albeit fast-following entrants into new emerging industries. Latecomers cannot afford to languish in any given industry because old industries continue to change, often becoming declining industries, and/or new industries are set up through the initiatives of the forerunners to take advantage of higher profits.

A notable feature here is that new industries in the advanced countries tend to be created by new, different firms, whereas in the latecomer countries, new emerging industries are developed by the same firms diversifying but possibly utilizing different access modes. For example, the Korean firms (Samsung or LG) have become highly diversified through entry into the manufacturing of numerous consumer goods.

Although such a dynamic change in the comparatively advantageous industries could evolve without state intervention, often some coordination by state agencies could expedite the process and provide a better chance of success.

\subsection{The roles of the developmental agency and industry targeting}

Gerschenkron, the great Russian economic historian, analysed the industrialization of Germany and Russia and introduced the notion of the 'latecomer effect' in the 1950s and 1960s (Lee and Mathews 2008). Gerschenkron (1962) notes that relative economic backwardness plays a role in inducing systematic substitution for the assumed prerequisites of industrial growth, and regards state intervention as necessary to compensate for the deficiencies. He points out that England, the locus of the industrial revolution, could advance with free market guidance along the lines of Adam Smith, but that France, beginning later, would have needed greater intervention to compensate for its limitations, and that in Germany, the key innovation would have been the formation of large banks to provide access to the capital needed for industrialization, just as Russia's greater backwardness required larger and more direct compensatory role by the state.

The situation confronted today by the developing world is worse than that faced by Germany or Russia, because many of these countries lag behind the leaders. Thus it is understandable if the developing countries seek special or more radical ways to compensate for their latecomer deficiencies.

Therefore, while the ultimate goal of development is to raise the capabilities of local private companies, pilot agencies are needed to guide and coordinate the whole process. Such needs exist because key resources are scarce, and should be mobilized for sectors or projects with the greatest externalities. As was understood by Gerschenkron who identified latecomer agencies—such as large state-owned investment banks-as the engines of process in Germany and Russia, it is such agencies that can compensate for gaps in a country seeking to industrialize.

All the east Asian countries set up specific state agencies that played a role in guiding the industrialization process. In Korea, the institutions established in the 1960s under the Park regime included the economic planning board to set economic plans; the ministry of trade and industry to support industrial policy and export; and the ministry of finance to fund 
the economic plans. These government agencies were important in targeting and promoting key industries and technologies in Korea, as is explained below.

The development process concerns growing industries, where firms can flourish and develop enhanced capabilities. But industries cannot be chosen randomly, or left to the whim of the multinational corporations. Enhancing the capabilities of private firms requires giving them the assurance of initial rents (profits) and learning opportunities until they mature enough to compete successfully in world markets. One effective way of assuring such opportunities is to target certain industries or technologies, such as those that exhibit externalities or market failure in terms of the gap between private and social return. While mainstream economics would focus only on such industries, we can go deeper than this and contend that there are more justified targets in the catching-up context.

The negative attitude towards targeting comes from the uncertainty of selecting the right industry or technology. For example, it is impossible to predict which industries or technologies are going to become prominent in a particular country. This concern, however, makes more sense in the context of the developed countries where firms are on the frontier of technology and are faced with greater uncertainty. But the latecomer economies have more justified targets: these are the industries or technologies that are being imported or purchased at prices monopolized by foreign companies. In this situation, targeted import-substitution transfers the rents from the foreign to local companies. With such a strategy of targeted import-substitution, local operations face less uncertainty or risk because the targeted technology often constitutes mature inventions that are possible to emulate through the concentrated efforts of local indigenous R\&D centres. Many successful examples abound in east Asia, including the development by the local R\&D consortium, TDX (digital telephone switches) in Korea in the early 1980s (Lee, Mani and Mu 2008).

Korea in the 1970s and 1980s faced a telephone service bottleneck. But the country had neither its own telecommunications equipment manufacturing industry nor an R\&D programme until the late 1970s. As a result, most of the equipment and related technologies were imported, and Korean technicians merely installed foreign switching systems into the nation's telephone networks.

With rapid development of its industrial and commercial bases and in population growth (approaching 36 million), telecommunications services in the late 1970s fell far behind the demand. After prudent consideration, Korea decided to build its own manufacturing capability and the R\&D infrastructure needed for the creation of state-of-the art digital phone switching systems.

In collaboration with a national network of switching system manufacturers and distributors, the Korean consortium and the Korean Electronics and Telecommunications Research Institute (ETRI) developed in 1981-83 a proprietary digital switching system called the TDX (time-division exchange) series. Thus development of the Korean system was phased through manual switch, step-by-step switch, skipping the crossbar switch to leapfrog to the analogue electronic switch and the digital electronic switch. This indigenous product took over markets previously dominated by imports and the MNCs. Korea's experience, accumulated and enhanced over the preceding decades, led to the growth of indigenous capabilities in wireless telecommunications in the 1990s. Similar take-over of the mobile phone market from 
Motorola to local Samsung and LG occurred around the millennium (Lee and Lim 2001).

These cases are indicative of how the Koreans, with the support of the government, were able to successfully overtake the markets previously held by the MNCs or JVs to become exporters. The preparation and cultivation of new industries necessitate stateled efforts by a variety of agencies, offering support ranging from the acquisition of land for firms destined in the designated industry, the acquisition of technology and the securing of finance including credit rationing, the adoption of nurturing strategies including tax concessions and R\&D subsidies, initial control of excessive competition to allow companies time to develop their products and markets, and a phased opening up to the full force of international competition. But, this state activism should be phased out at later stages because the costs of local production and risks of entering new markets will have been reduced due to the dynamic learning effects that result from the cumulative output produced.

\section{The process of catch-up: some elaborations}

\subsection{The catching-up efforts in its early days (the 1960 s to the mid 1970 s) ${ }^{1}$}

\section{Low technological capability and technology imports with licensing}

In the 1960s when Korea started to modernize with export drives, its human capital base was very poor: in 1965, enrolment for primary school was 29.6 per cent, 10.9 per cent for secondary schooling, and a mere 2.6 per cent for tertiary education (World Bank 2005). The catch-up efforts during this period relied mostly on imported turnkey-based technology, and there was a serious shortage of technical personnel able to operate the imported equipment based on on-site instructions or manuals. Thus the main emphasis was on bringing up the general level of human capital, and by the mid 1970s, there was considerable improvement compared to the previous decade. In 1975, primary school enrolment was 106.86 per cent, and secondary and tertiary rates 56.35 per cent and 6.9 per cent, respectively (ibid.).

In the late 1960s, the Korea government also recognized the need for advanced training for scientists and engineers in preparation for developing indigenous technologies. In 1972, the government set up a new graduate school of engineering and applied sciences, the Korea Advanced Institute of Science (KAIS), later renamed KAIST (the Korea Advanced Institute of Science and Technology). KAIS has served as a crucial scientific and technological institute by ensuring, with adequate research funding, elite education for the best minds of the country.

The technology capability of the domestic firms was poor as well, and exported goods were based on OEM production by assembling or processing imported parts and raw materials. The level of technological investment was extremely low; R\&D expenditure in 1965 was only 0.26 per cent of the GNP, never exceeding 0.5 per cent of GDP during the 1960s and 1970s (Table 3). Nevertheless, domestic firms had to make an effort to

1 This section relies partly on Lee and Kim (2008). 
Table 2

Building of technological capacity in Korea

\begin{tabular}{|c|c|c|c|c|c|c|c|}
\hline & \multicolumn{2}{|c|}{$R \& D$ in Korea } & \multicolumn{5}{|c|}{ Patent applications in Korea } \\
\hline & $\begin{array}{c}\text { R\&D/GDP } \\
(\%)\end{array}$ & $\begin{array}{l}\text { Private } \\
\text { share }\end{array}$ & Total & Non-resident & Resident & $\begin{array}{l}\text { Resident } \\
\text { share }\end{array}$ & $\begin{array}{c}\text { Corporate } \\
\text { share }\end{array}$ \\
\hline 1960 & & & 611 & 66 & 545 & 89.2 & 4.1 \\
\hline 1961 & & & 858 & 58 & 800 & 93.2 & 4.9 \\
\hline 1962 & & & 782 & 68 & 714 & 91.3 & 5.5 \\
\hline 1963 & 0.24 & & 771 & 101 & 670 & 86.9 & 11.6 \\
\hline 1964 & 0.20 & & 908 & 164 & 744 & 81.9 & 12.4 \\
\hline 1965 & 0.26 & & 1,018 & 160 & 858 & 84.3 & 10.6 \\
\hline 1966 & 0.31 & & 1,060 & 177 & 883 & 83.3 & 15.3 \\
\hline 1967 & 0.37 & & 1,177 & 322 & 855 & 72.6 & 10.3 \\
\hline 1968 & 0.41 & & 1,463 & 377 & 1,086 & 74.2 & 20.2 \\
\hline 1969 & 0.45 & & 1,701 & 547 & 1,154 & 67.8 & 20.4 \\
\hline 1970 & 0.37 & 18.37 & 1,846 & 639 & 1,207 & 65.4 & 21.4 \\
\hline 1971 & 0.31 & & 1,906 & 623 & 1,283 & 67.3 & 24.0 \\
\hline 1972 & 0.28 & & 1,995 & 618 & 1,377 & 69.0 & 15.9 \\
\hline 1973 & 0.29 & & 2,398 & 776 & 1,622 & 67.6 & 28.1 \\
\hline 1974 & 0.30 & & 4,455 & 3,362 & 1,093 & 24.5 & 17.1 \\
\hline 1975 & 0.42 & & 2,914 & 1,588 & 1,326 & 45.5 & 24.3 \\
\hline 1976 & 0.43 & 35.20 & 3,261 & 1,825 & 1,436 & 44.0 & 27.8 \\
\hline 1977 & 0.59 & 52.24 & 3,139 & 1,962 & 1,177 & 37.5 & 36.4 \\
\hline 1978 & 0.62 & 51.16 & 4,015 & 3,021 & 994 & 24.8 & 33.2 \\
\hline 1979 & 0.55 & 45.54 & 4,722 & 3,688 & 1,034 & 21.9 & 26.4 \\
\hline 1980 & 0.56 & 48.39 & 5,070 & 3,829 & 1,241 & 24.5 & 24.0 \\
\hline 1981 & 0.62 & 56.37 & 5,303 & 3,984 & 1,319 & 24.9 & 18.3 \\
\hline 1982 & 0.84 & 58.72 & 5,924 & 4,368 & 1,556 & 26.3 & 22.8 \\
\hline 1983 & 1.13 & 72.55 & 6,394 & 4,795 & 1,599 & 25.0 & 19.3 \\
\hline 1984 & 1.22 & 78.63 & 8,633 & 6,619 & 2,014 & 23.3 & 39.6 \\
\hline 1985 & 1.41 & 80.53 & 10,587 & 7,884 & 2,703 & 25.5 & 44.7 \\
\hline 1986 & 1.59 & 80.92 & 12,759 & 9,118 & 3,641 & 28.5 & 57.9 \\
\hline 1987 & 1.65 & 79.60 & 17,062 & 12,191 & 4,871 & 28.5 & 66.0 \\
\hline 1988 & 1.72 & 82.27 & 20,051 & 14,355 & 5,696 & 28.4 & 72.5 \\
\hline 1989 & 1.75 & 82.89 & 23,315 & 16,294 & 7,021 & 30.1 & 77.3 \\
\hline 1990 & 1.72 & 84.06 & 25,820 & 16,738 & 9,082 & 35.2 & 80.0 \\
\hline 1991 & 1.84 & 80.38 & 28,132 & 14,879 & 13,253 & 47.1 & 82.3 \\
\hline 1992 & 1.94 & 82.39 & 31,073 & 15,121 & 15,952 & 51.3 & 82.8 \\
\hline 1993 & 2.12 & 83.11 & 36,491 & 15,032 & 21,459 & 58.8 & 83.5 \\
\hline 1994 & 2.32 & 76.15 & 45,712 & 17,148 & 28,564 & 62.5 & 85.4 \\
\hline 1995 & 2.37 & 75.74 & 78,499 & 19,263 & 59,236 & 75.5 & 93.4 \\
\hline 1996 & 2.42 & 73.67 & 90,326 & 21,913 & 68,413 & 75.7 & 90.4 \\
\hline 1997 & 2.48 & 72.45 & 92,734 & 25,388 & 67,346 & 72.6 & 90.6 \\
\hline 1998 & 2.34 & 69.13 & 75,188 & 24,592 & 50,596 & 67.3 & 83.3 \\
\hline 1999 & 2.25 & 69.96 & 80,642 & 24,672 & 55,970 & 69.4 & 76.3 \\
\hline 2000 & 2.39 & 72.38 & 102,010 & 29,179 & 72,831 & 71.4 & 68.4 \\
\hline 2001 & 2.59 & 72.46 & 104,612 & 30,898 & 73,714 & 70.5 & 72.9 \\
\hline 2002 & 2.53 & 72.20 & 106,136 & 29,566 & 76,570 & 72.1 & 75.5 \\
\hline 2003 & 2.63 & 74.01 & 118,652 & 28,339 & 90,313 & 76.1 & 77.4 \\
\hline 2004 & 2.85 & 74.96 & 140,115 & 34,865 & 105,250 & 75.1 & 79.8 \\
\hline 2005 & 2.98 & 74.96 & 160,921 & 38,733 & 122,188 & 75.9 & 80.9 \\
\hline
\end{tabular}

Source: Author's computation based on Korea Statistical Yearbook (various years): KIPO (Korea Intellectual Property Office); Yearbook of Intellectual Property (various years). 
overcome the poor technological capabilities by investing in learning foreign technology from the advanced countries, which consisted mainly of assembling technology and packaged technology, for example, turnkey-based plants. Further learning efforts were concentrated mainly on operational technology through informal channels such as the purchase of capital goods or reverse engineering (L. Kim 1997). As shown in Table 4, imports of capital goods amounted to US\$3,154 million during 1962-71. In contrast, technology imports 2 over the same period were a mere US\$21.2 million.

Table 3

Changing modes of accesses to foreign technologies in Korea (mil. US \$, \%)

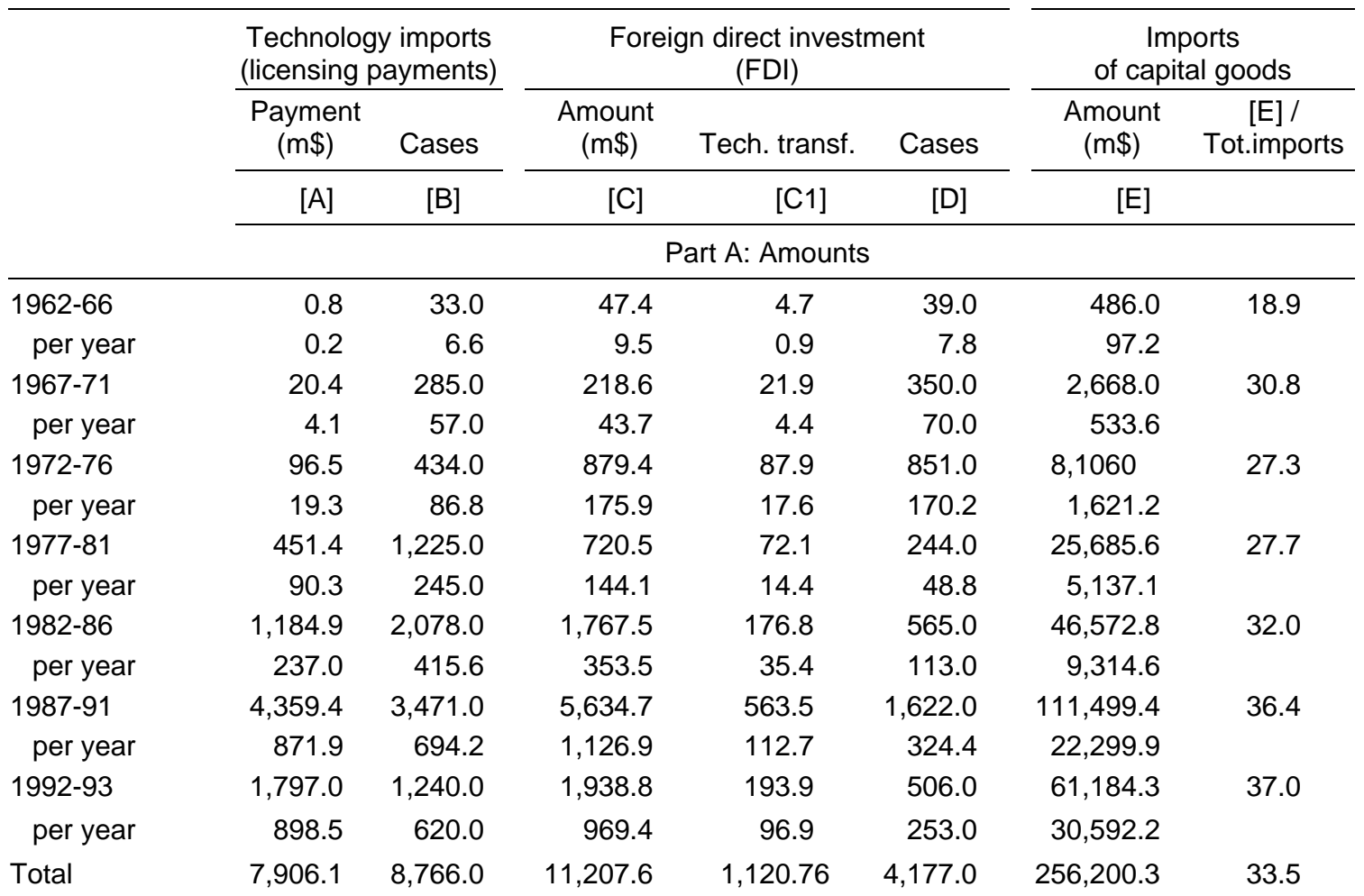

Part B: Ratios

\begin{tabular}{lccc} 
& $\begin{array}{c}\text { Capital goods / Tech. } \\
\text { imports (E/A) }\end{array}$ & $\begin{array}{c}\text { Imports of capital goods / FDI } \\
(\text { E/C) }\end{array}$ & $\begin{array}{c}\text { Tech. imports / (Tech. } \\
\text { transf. via FDI) (A/C1) }\end{array}$ \\
\cline { 2 - 4 } $1962-66$ & 607.5 & 10.3 & 0.2 \\
$1967-71$ & 130.8 & 12.2 & 0.9 \\
$1972-76$ & 84.0 & 9.2 & 1.1 \\
$1977-81$ & 56.9 & 35.6 & 6.3 \\
$1982-86$ & 39.3 & 26.3 & 6.7 \\
$1987-91$ & 25.6 & 19.8 & 7.7 \\
$1992-93$ & 34.0 & 31.6 & 9.3 \\
\hline Notes: & Technology transfer through FDI is assumed to be 10\% of FDI amounts for rough comparison \\
& with technology imports (payments for licensing). & \\
Source: & Author's adaptation using data from the Bank of Korea, Korea Industrial Technology Association \\
& (KITA), as cited in OECD (1996: 83).
\end{tabular}

2 The term 'technology imports' means technology imported with the technological licensing or technical assistance needed to train local engineers to run turnkey plants. 
Although technology imports were low, government policies were established to stimulate the importation of foreign technology. There were laws on capital goods imports, foreign loans and technology imports, including the Foreign Capital Inducement Act (1966). For effective control of technology, guidelines were issued (1968) to prioritize technologies that promoted exports, developed intermediate capital goods industries or had an awareness-promoting effect. A ceiling on royalties was set at 3 per cent as well as a five-year duration. However, in 1970 and 1978, to encourage the influx of technology, policy changes were introduced to allow for a higher royalty rate (Kim 1997: 39). In 1972, the Technology Development Act was introduced to stimulate technology imports, and a year later, the Foreign Capital Inducement Act was revised to relax the approval criteria and facilitate technology import procedures (OECD 1996: 87). Moreover, key institutions for science and technology infrastructure began to be established. For example, the Korea Institute of Science and Technology, the country's first multidisciplinary governmental research institute, was founded in 1966, and the Bureau of Science and Technology was set up in 1967.

The Foreign Capital Act certainly contributed to attracting FDI inflows, as export and import procedures for foreign companies were simplified. In the electronics industry, for example, Fairchild Semiconductors, Signetics and Motorola capitalized 100 per cent in Korea and began to produce transistors and IC. In 1969, Toshiba Korea was established and Toshiba (Japan) invested 70 per cent of its capitalization (Bae 1995). However, these FDI-funded operations had been set up to take advantage of Korea's low wages, as they all used imported intermediate goods, including transistors. Indeed, core technology absorption such as design or wafer processing was not expected. The turning point of the industry began with the founding of Korea Semiconductor, later acquired by Samsung, which aimed at wafer processing. This company was established in January 1974 with investments by both KEMCO (Korea Engineering and Manufacturing Company) and ICII (Integrated Circuit International Inc.), the US subsidiary of KEMCO. The Korea Semiconductor succeeded in developing the transistor with its own IPR-based technology and contributed to building up the local technological base that was developed further after its acquisition by Samsung.

\subsection{Beginning of the catching-up phase (mid 1970s to the mid 1980s)}

\section{Active importation of foreign technology and the beginning of $R \& D$ investment}

This stage is characterized by the active importation of foreign technologies by Korean firms for imitative innovation (L. Kim 1997). From the mid 1970s when the economy shifted towards heavy and chemical industries, and large firms emerged, forming the chaebol groups, Korean enterprises invested intensively in learning foreign technology to gain a share of the market in skill-intensive industries. In order to stimulate the technology inflow needed to modernize its heavy industries, Korea had to substantially relax import criteria. This was done, for example, by introducing in 1984 a system of automatic approval for technology imports, which replaced the earlier reporting system (OECD 1996: 88).

Imported technology was unpackaged technology: parts and components and operational technology. Formal channels of learning such as technical licensing became important for securing access to advanced technology. Table 3 shows that technology 
imports in the 1982-86 period totalled US\$1,184.9 million, which is 8.1 times more than in the corresponding period a decade earlier.

Foreign firms from the early 1980s onward were increasingly reluctant to grant technology licenses to Korean enterprises, because the Koreas were attempting to enter the skill-intensive markets dominated by the advanced countries. Thus, investment in R\&D was required not only for absorbing advanced technology but also for developing Korea's own technological capabilities. Consequently, R\&D expenditures increased from 42.7 billion won in 1975 to 1,237.1 billion won in 1985, or as a share of GNP, increasing from 0.42 per cent to 1.41 per cent, respectively. It was the first time since 1983 that the $R \& D$ ratio was more than 1 per cent (see Table 2).

Also, the Science and Technology Promotion Law was enacted, providing a legal basis for various promotion measures. The Special National R\&D Programme was launched in 1982 with a total investment of 334 billion won, of which the government invested 194 billion won and private sector 140 billion won (Branscomb and Choi 1996: 22). Overall, during this period, the role of the government was greater than that of the private sector.

\subsection{The rapid catch-up (the mid 1980s to the mid 1990s)}

\section{The establishment of in-house $R \& D$ centres of Korean firms}

The third phase from the mid 1980s to the mid 1990s is the period of rapid catch-up led by the major Korean businesses. Firms were increasing production of knowledgeintensive products in the major manufacturing industries such as the electronics, automobile and mechanical engineering industries. Large firms became internationalized, extending outward foreign investment into cheaper wage-sites in southeast Asia, expanding into the early stages of becoming multinational companies. After accumulating capability for process improvement, firms started to initiate product innovation (OECD 1996: 82). Domestic firms imported technology related to materials, control, design as well as high-quality product technology (ibid.: 82). Exported goods were produced with both OEM and own brand names, with brand name exports becoming more common (ibid.: 82).

From the mid 1980s, the Korean firms, realizing the limitation of the licensing and embodied technology transfer, started to establish their own in-house R\&D centres (OECD 1996). R\&D expenditures rose rapidly, as indicated by their increased share in GNP, from 1.4 per cent in 1985 to 2.32 per cent in 1994. In order to encourage R\&D activities by private firms, the government eased the prior approval criterion needed for $R \& D$ institutes, and a large number of institutes were set up. When the system for registering private research institutes was first introduced in 1981, the scheme had provided tax waivers for private research institutes, military service exemption for research personnel, and tariff exemption for research equipment (OECD 1996: 95). In 1985, to encourage the establishment of research institutes in small firms, the government reduced the required number of research personnel from 10 to 5 (ibid.: 95). Large domestic firms eventually began to recognize the importance of in-house R\&D for accumulating the technology development capability needed to gain a share of the market in skill-intensive industries, and established R\&D centres during the late 1970s and early 1980s, bringing the number up from 65 institutes to 183 by the year 1985 . Overseas branches of private $R \& D$ institutes were also set up in order to access foreign 
sources of knowledge and to be aware of recent technology development; by 1994 there were 51 overseas $R \& D$ centres (ibid.: 97).

Such active engagement of private R\&D activities enabled Korea eventually to absorb the newly emerging technology. The best example is the mobile digital communication technology CDMA. Although analogue mobile communication systems were still dominant in most advanced countries, Korea moved forward and started R\&D on a digital system in 1989. On the basis of R\&D conducted in governmental and private research institutes, domestic firms and governmental research institutes were in a position to absorb knowledge of the mobile digital telecommunication systems through their cooperation with Qualcomm, an American venture company (Lee and Lim 2001). The $R \& D$ focused on absorbing emerging technology is linked $R \& D$ geared to commercialization.

\subsection{Maturing of the catching-up phase (the mid 1990s to the present)}

This is the period when Korea joined the club of the advanced countries, namely the Organization of Economic Cooperation and Development (OECD). But it was also the period when the country suffered a financial crisis, and was faced with a comprehensive economic reform imposed by IMF conditionality.

Partly because of his desire to leave a lasting imprint on the modern history of Korea, President Kim Young-sam in 1993 endorsed the plan to join the OECD, setting December 1996 as the entry date. Without attempting serious labour, financial and chaebol reform, Korea confronted the borderless global capital markets as a country characterized by a real sector that survived on bank subsidies, plagued by labour market rigidities, and entrapped in an opaque corporate governance structure (Lee et al. 2008). In 1997, exactly one year after OECD entry, Korea was faced with a financial crisis.

The post-crisis reform package for Korea was one of the most comprehensive and decisively implemented set of reforms undertaken by any country following a major crisis. Korea became an almost totally open economy in every respect, including capital market liberalization, direct foreign investment (FDI) and importation of foreign goods. In consequence, there was a massive influx of FDI, rising from US\$6,971 million in 1997 to US\$8,852 million in 1998, and to US\$15,541 million in 1999. This influx is, without a doubt, related to the new Foreign Investment Promotion Act enforced on 17 November 1998, that provided foreign investors with improved supporting services and increased incentives in efforts to attract foreign investments.

Now, ten years later, many observers are concerned that the reforms have jeopardized the long-run sustainability of economic growth, as there is increasing recognition of both the benefits and costs of the reforms (Lee and Lee 2008). While the reforms have thrust Korean firms into a more stable and transparent business environment, major economic indicators have been less robust, with a downward shift of 5 percentage points in gross investment rates relative to GDP. Some critics - for example, Chang and Shin (2002) — argue that this is the price that must be paid for transferring to an economic model (the Anglo-Saxon model) that is not suitable for a country just graduating to developed status.

The big business sector is the one that went through substantial reforms, because the chaebols and the related excessive investment and foreign borrowing were criticized as 
one of the important causes of the crisis. Radical restructuring was inevitable, as approximate one-third of the top 30 chaebols went bankrupt. According to Choo et al. (2009), investment inefficiency was a critical factor in the productive inefficiency of the 1990s or the pre-crisis period, and that the post-crisis turnaround of the surviving chaebols was based on correcting the source of this ineffectiveness. But more importantly, this study confirms that technological capabilities are an important factor in explaining the post-crisis performance of the surviving chaebols. This implies that the only enterprises that succeeded in building a degree of capability survived the crisis. Through post-crisis restructuring, the remaining chaebols re-emerged as attractive, profitable global players with very low debt ratios and very high foreign shareholdings.

This firm-level study is consistent with the aggregate trend of technological capability measured according to patent data. First, among Korean patents, the share of patents applied by domestic firms rose to 93 per cent, with large firms the main domestic inventors. These accounted for the rapid accumulation of technological capability since they were the firms that had initiated R\&D activities during the third catch-up period. For example, the top ten Korean firms in terms of patent registration owned 62.4 per cent of the patents granted in the country in 1999. Korean patents granted to foreigners also increased rapidly, from 5,937 in 1995 to 12,013 in 2000. The most impressive feature of the period was the increased number of local entities among the successful patent applicants granted in Korea, their share rose from 52.5 per cent in 1995 to 65.6 per cent in 2000 (see Figure 2).

More importantly, according to a US register, patents owned by Koreans increased from seven in 1982 to 3,558 in 1999, while the country's share in total US patents went from 0.01 per cent to 2.09 per cent over the same period. Korea ranked sixth in terms of patents granted in the US in 1999, behind the US, Japan, Germany, the UK and Taiwan. France was seventh. This rapid increase in the number of Korean-held patents is mainly due to the improved indigenous technological capabilities of inventors residing in Korea as the result of R\&D activities in the country.

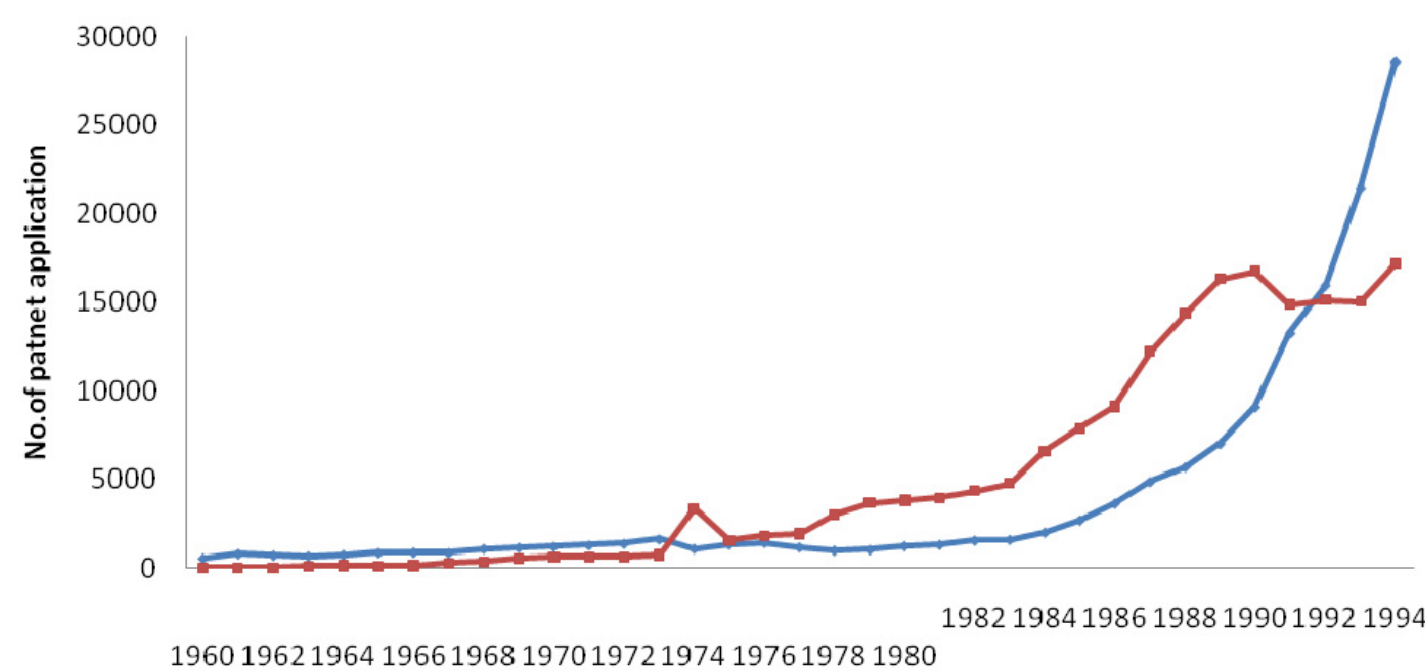

Source: Lee and Kim (2008). 


\section{Summary of the process in terms of the capability building and learning}

\subsection{Stages of capability building}

Development is considered to be a process of learning and capability. Thus, securing access to existing knowledge bases determines the success of catching-up because latecomer firms do not command sufficient capability to generate knowledge by themselves. While it is natural for advanced economies to create most of this knowledge stock, and non-advanced economies try to tap into this stock, they are constrained by the limited channels of knowledge diffusion and their abilities to absorb and adapt new knowledge. In this way, the knowledge from advanced countries has the function of facilitating technological development in catch-up economies. Hence, the extent of knowledge diffusion from advanced countries to developing economies in each sector is a critical element for the catching-up process. Industry case studies, such as Lee and Lim (2001) and Mu and Lee (2005) as well as the econometric studies by Park and Lee (2006), confirm the importance of gaining access to an external knowledge base, and the high probability of failure of isolated attempts to indigenously develop imported technology.

In arranging access and learning opportunities for foreign knowledge acquisition, it is important to note that there are quite diverse channels of knowledge diffusion, and these vary across industries or at different stages of economic development. Alternative channels include informal learning, learning from OEM, licensing, FDI, strategic alliance, co-development, and so on. The experience of Korea allows us to identify a sequential pattern in the evolution of the channels of access to foreign knowledge.

In the earliest stage of capability-building, as in Korea in the 1960s and early 1970s, the primary channel of learning is technical guidance from foreign OEM buyers or learning by working in FDI firms. Key technology is embodied in imported machinery and equipment. It is basically learning-by-doing with no capacity nor intention of technological development.

During the next stage, when the latecomer firms recognize the need for more systemic learning and technological development, such firms tend to resort to technological licensing, which was Korea's main form of acquisition of foreign technology in the mid 1970s and the 1980s, or they actively seek knowledge transfer from any FDI partner. During this stage, the critical factor for effective learning would be the absorptive capacity of the latecomer firms, which also depends on the country's education system and other elements of the national innovation system.

During the third stage, corresponding to the mid 1980s in Korea, the latecomer firms establish a certain degree of in-house R\&D capacity with a clear idea of what should be done and how much resources are to be allocated.

The fourth stage concerns the period when licensing or learning from foreign partners has reached its limits. Latecomer firms should now rely on public-private R\&D consortia, research of the existing literature, overseas R\&D outposts, co-development contracts with foreign R\&D or technology specialist firms and/or international mergers and acquisitions (M\&As). It was also from the early 1990s that a small number of Korean firms began to establish overseas R\&D posts, mainly in order to obtain easy and faster access to foreign technology that was difficult to acquire through licensed 
imports. These overseas posts also served as a window on recent trends in technological development (OECD 1996: 97).

The final stage, characterizing Korea since the late 1990s, is the horizontal collaboration or alliance based on complementary assets. Some firms, such as Samsung, have reached this stage, and are now engaged with Intel, Sony, Toshiba, and MS in diverse modes of alliances.

These changes in the modes of access to foreign technologies are shown in Table 3. In earlier decades, the value of capital goods imports was far greater than the amounts paid in the form of licensing for imported technology, with a ratio as high as 130 prior to the 1970s. This has continued to decrease to less than 30 in the 1990s, as Korea shifted towards more licensing after the mid 1970s. It is also noteworthy that throughout the entire period, the value of capital goods imported by Korea far exceeded the amounts the country was able to attract in FDI. FDI began to increase substantially after FDI liberalization in the late 1980s, when annual average amount increased from US\$353 million to US\$1,126 million.

Achievements through in-house R\&D can be shown by the ratio of Korean patents filed by Koreans compared to those filed by foreigners (Figure 3). Prior to the 1970s, foreigners had no interest in Korean intellectual property rights (IPRs) and no patents were filed, which led to the dominant share of domestic patents until the 1980s when the trend was reversed, with foreigners filing the most of patents. Once the capabilities of domestic investors improved, their share increased sufficiently to overtake the share of foreigners, a situation existing in Korea since the mid 1990s. Lee and Kim (2008) observe that such a dynamic pattern is evident in the other catching-up economies of Japan, Taiwan and recently China.

\subsection{The first half of the 1980 s as the critical juncture}

Rodrik (2006: 974) contents that while the lessons drawn by proponents and sceptics may differ, it is fair to say that nobody really believes in the Washington consensus anymore, and that the question is not whether the consensus is dead or alive but what will replace it. After the credibility of the Washington consensus faded, it has been augmented by a long list of the so-called 'second generation' reforms that are heavily institutional in nature (Rodrik 2006). Also, an important work by the Growth Commission (Commission on Growth and Development 2008) was made public, which acknowledged the importance of government activism and industrial policy, while expressing caution for hasty liberalization and privatization.

However, it is striking to see that both the augmented list and the 2008 Growth Commission report still consider the building of technological capabilities by private firms as a marginal issue. In our view, the east Asian evidence indicates that this is a genuine, binding constraint that can limit sustained growth. Rodrik points to the importance of inhibiting constraints, but does not attempt to identify what exactly these constraints might be. Lee and Kim (2009) prove with cross-national regressions that for middle-income countries, limited $\mathrm{R} \& \mathrm{D}$ and college education have been the obstacles for long-run growth, whereas for low-income countries, these are the scanty basic political institutions and primary/secondary education. 
The discussion so far suggests that in the early to mid 1980s, Korea based its transition from a middle- to a high-income country by enhancing its technological capabilities. At that time, the R\&D/GDP ratio was close to the threshold level of 1 per cent, the share of private R\&D exceeded 70 per cent, and the share of corporate patents surpassed those by individual inventors. Based on these capabilities, Korea evolved into a high-income country with a per capital GDP in the 1980s of approximately US\$1,673 in nominal terms and US\$3,223 in 2000 dollar terms. By the year 2000, this had increased to US\$10,890 (Lee and Kim 2009: table 1).

Tertiary school enrolment jumped from around 10 per cent in 1980 to more than 30 per cent five years later, and finally surpassed 70 per cent in 2000 (Lee 2006: table 5). The R\&D/GDP ratio was around 0.7 per cent in 1980, 1.5 per cent in 1985 and almost 2 per cent in 2000. In contrast, trade/GDP ratio was 70 per cent already in 1980 and has stayed around that level until 2000. These figures clearly indicate that the transition was made possible not by better opportunities, but by capability-building associated with tertiary education and private R\&D.

\section{The issue of transferability}

Now if we consider such capability-building as the core of the Korean model, the emerging question then is whether a similar process is possible in other countries. The simple answer seems to be yes. The first thing other latecomer or Latin American economies should to do is to take steps to increase the ratio of R\&D/GDP and college enrolment, the two indicators where these economies are lagging. Of course, such an improvement is possible and effective only in conjunction with substantial changes in other economic policies and institutional environment, including the autonomy and capacity of the government. This could be the difficult part.

One necessary issue is changing the perception of the role of government. We are all aware about the costs of the 'visible foot' or government failure, which often leads to rent-seeking behaviour. We can point to two elements in the Korean model that could curb the potential for rent-seeking. The first is outward or export orientation where any preferential resource allocation has to be based on the performance of the exporting firms. As explained above, export orientation imposes a market discipline that cannot be offered by the domestic market to protected producers, and thereby poses a set of constraints on domestic economic policies (C. Lee 1992). The second element is the fact that the Korean model is strongly biased towards generating new sources of growth, new rents as well as removing rents from foreign firms, and these tend to lighten any potential burden. In other words, the rules of game are not so much about the redistribution of rent among domestic agents, as about the creation and generation of new rents. For example, in Korea the preferential and targeted public and private R\&D consortium for indigenously developing the digital telephone switches was to create new sources of rent for local products competing against foreign goods.

A second issue concerns the new environment created by general global trading conditions and those by WTO, such as the new rules for intellectual property protection (TRIPS), for trade-related investment measures (TRIMS) and the general agreement on trade in services (GATS). These codes impose stringent restrictions on the rights of the developing countries to deploy many of the institutions and policy settings that were 
available to Korea, such as infant industry protective tariffs and restraints on inward FDI and foreign exchanges.

But enterprising countries may find ways to work around these restrictions, particularly in areas that can be considered 'innovation', rather than trade or development. As is well-known, the WTO rules allow substantial room for state subsidies for R\&D expenditure. The US conducts considerable state-led R\&D in the name of defencerelated research, and innovative developing countries will follow its example. Developing countries can pay more attention to their 'national systems of innovation', not only because R\&D conducted through government research institutes is important in developing domestic technological capabilities, but also because this provides a path through the tangle of WTO rules and restrictions. The WTO allows some discretion in policies to support the small and medium enterprises (SMEs) as well as export subsidies in countries with a per capita income below US\$1,500.

Third, given our emphasis on promoting private companies as the engine of growth, one might ask whether more or less independent and indigenously owned companies are necessary for successful catch-up, and whether it is feasible to rely on foreign MNCs or FDI. As is known, MNCs are the places for learning and the sources of knowledge diffusion for local firms as these try continuously to move upward for higher valueadded activities in the global chain. But we would like to point out that in order to succeed with a strategy of more involvement with the MNCs, several other elements identified in the Korean model are required in addition to the generally high level of educational attainment. They include: creating and relying upon the pilot (coordinating) state agencies to guide industrialization, targeting industries/technologies for (importsubstituting) development and shifting taking rents away from foreign companies; and sequential upgrading for changing/dynamic comparative advantages. Together these elements mean an active role by the government. The Taiwan SMEs are an example. The Taiwan SMEs were set-up as suppliers to the MNCs or joint ventures, but more and more of these eventually developed into firms with greater local ownership and control, as noted by Amsden and Chu (2003). This was possible because the disadvantages of 'smallness' were overcome by the government's more active intervention (Mathews 2002). In particular, the SMEs in sectors with greater capital requirements or more risk were helped by government research institutes which provided sources of new knowledge in the form of joint $R \& D$ consortia and/or new spinoff firms from the government sector. 


\section{References}

Amsden, A. (1989). Asia’s Next Giant. New York: Oxford University Press.

Amsden, A., and W.-W. Chu (2003). Beyond Late Development: Taiwan's Upgrading Policies. Cambridge, MA: MIT Press.

Bae, Y.-H. (1995). 'Technology Absorption and R\&D in the Korean Semiconductor Industry: The Case Study of Samsung Electronics Co.'. Korea: Seoul National University. PhD thesis.

Chang, H.-J. (1994). The Political Economy of Industrial Policy. New York: St. Martin Press.

Chang, S. J. (2003). Financial Crisis and Transformation of Korean Business Groups. The Rise and Fall of Chaebol. Cambridge: Cambridge University Press.

Chang, H.-J., and J. Shin (2002). Restructuring 'Korea Inc.': Evaluating the Post-crisis Corporate Restructuring in Korea.

Choo, K., K. Lee, K. Ryu, and J. Yoon (2009). 'Changing Performance of the Business Groups over Two Decades: Technological Capabilities and Investment Inefficiency in Korean Chaebols'. Economic Development and Cultural Change, 57 (2): 359-86.

Commission on Growth and Development (2008). The Growth Report: Strategies for Sustained Growth and Inclusive Development. Washington, DC: World Bank.

Dahlman, C., L. E. Westphal, and L. Kim (1985). 'Reflections on Acquisition of Technological Capability'. In N. Rosenberg and C. Frisctak (eds), International Technology Transfer: Concepts, Measures and Comparisons. New York: Pagamon.

Gerschenkron, A. (1962). Economic Backwardness in Historical Perspective. Cambridge, MA: The Belknap Press of Harvard University Press.

Hobday, M. (1995). Innovation in East Asia: The Challenge to Japan. Cheltenham: Edward Elgar.

Hobday, M. (2000). 'East versus Southeast Asian Innovation Systems: Comparing OEM- and TNC-led Growth in Electronics'. In L. Kim and R. Nelson (eds), Technology, Learning and Innovation. Cambridge: Cambridge University Press.

Kim. L. (1996). Imitation to Innovation. Cambridge, MA: Harvard Business School Press.

Lall, S. (1996) Learning from the Asian Tigers: Studies in Technology and Industrial Policy. London and New York: Macmillan and St. Martin's Press.

Lee, C. (1992). 'The Government, Financial System, and Large Private Enterprises in the Economic Development of South Korea’. World Development, 20 (2): 187-97.

Lee, C., and K. Lee (2008). 'The Miracle to Crisis and the Mirage of the Post-crisis Reform in Korea: An After-Ten year Assessment'. Journal of Asian Economics, 19 (5-6): 425-37.

Lee, K. (2005). 'Making a Technological Catch-up: Barriers and Opportunities'. Asian Journal of Technology Innovation, 13 (2): 97-131. 
Lee, K. (2006). 'The Washington Consensus and East Asian Sequencing: Understanding Reform in East and South Asia’. In J. Fanelli and G. McMahon (eds), Understanding Market Reforms, vol. 2. London: Palgrave-Macmillan.

Lee, K., and Y. Kim (2008). 'IPRs and Technological Catch-up in Korea'. Paper presented at the Tokyo Meeting on IPRs and Technological Catch-up, 12-13 January.

Lee, K., and B. Y. Kim (2009). 'Both Institutions and Policies Matter but Differently for Different Income Groups of Countries: Determinants of Long-Run Economic Growth Revisited'. World Development, 37 (3): 533-49.

Lee, K., and C. Lim (2001). 'Technological Regimes, Catch-up and Leapfrogging: Findings from the Korean Industries’. Research Policy, 30.

Lee, K., and J. Mathews (2008). 'Successive Upgrading in the Same Industry and Entries into New Industries for Sustained Growth: Firms from Korea and Taiwan'. Paper presented at the Workshop on Catch-up and Innovative Firms held 21-23 September, Mexico City.

Lee, K., S. Mani, and Q. Mu (2008). 'Explaining Divergent Stories of Catch-up in the Telecommunication Equipment Sector: Comparing China, India, Brazil and Korea'. Paper presented at the Globelics Conference, 22-24 September. Mexico City.

Lee, K., B. Kim, C. Lee, and J. Yee (2008). 'Visible Success and Invisible Failure in Post-Crisis Reform in Korea'. Development and Society, 37 (1): 23-53.

Mathews, J. A. (2002). 'The Origins and Dynamics of Taiwan’s R\&D Consortia'. Research Policy, 31: 633-51.

Mathews. J. A. (2005). 'Strategy and the Crystal Cycle'. California Management Review, 47 (2): 6-31.

Mathews, J. A. (2006). 'Catch-up Strategies and the Latecomer Effect in Industrial Development’. New Political Economy, 11 (3): 313-36.

Mathews, J. A., and D. S. Cho (2000). Tiger Technology: The Creation of a Semiconductor Industry in East Asia. Cambridge: Cambridge University Press.

Mu, Q., and K. Lee (2005). 'Knowledge Diffusion and Technological Leapfrogging: the Case of Telecommunication Industry in China’. Research Policy, 34 (6): 759-83.

Ocampo, J. A. (ed.) (2005). Beyond Reforms: Structural Dynamics and Macroeconomic Stability. Stanford: Stanford University Press for the ECLAC.

OECD (Organization for Economic Cooperation and Development) (1992). Technology and Economy: The Key Relationships. Paris: OECD.

OECD (1996). Reviews of National Science and Technology Policy: Republic of Korea, Paris: OECD.

Park, K., and K. Lee (2006). 'Linking Technological Regimes and Technological Catchup: Analysis of Korea and Taiwan Using the US Patent Data'. Industrial and Corporate Change, 16: 4 (July).

Rodrik, D. (1996a). 'Coordination Failures and Government Policy: A Model with Applications to East Asia and Eastern Europe'. Journal of International Economics, $40(1 / 2): 1-22$. 
Rodrik, D. (1996b). 'Understanding Economic Policy Reforms'. The Journal of Economic Literature, 34 (1): 9-41.

Rodrik, D. (2006). 'Goodbye Washington Consensus, Hello Washington Confusion? A Review of the World Bank's Economic Growth in the 1990s: Learning from a Decade of Reform'. Journal of Economic Literature, 44 (4): 973-87.

Teece, D. (2000). 'Firm Capabilities and Economic Development'. In L. Kim and R. Nelson (eds), Technology, Learning and Innovation. Cambridge: Cambridge University Press.

Utterback. J. M., and W. J. Abernathy (1975). 'A Dynamic Model of Process and Product Innovation'. Omega, 3 (6): 640-56.

Vernon, R. (1966). 'International Investment and International Trade in the Product Cycle’. Quarterly Journal of Economics, 80: 190-207.

World Bank (1993). The East Asian Miracle: Economic Growth and Public Policy. New York: Oxford University Press.

World Bank (2005). Economic Growth in the 1990s: Learning from a Decade of Reform. Washington, DC: World Bank. 